COGNitive STUdies | ÉTUdES COGNitiVes, 15: 35-42

DOI : $10.11649 / \mathrm{cs} .2015 .003$

\author{
ALLA LUCHYK \\ National University of "Kyiv-Mohyla Academy", Kyiv, Ukraine \\ allal@meta.ua

\section{THE SLAVIC TRANSLATION LEXICOGRAPHY THEORY AND PRACTICE: ON THE MATERIAL OF THE STABLE WORD UNITS}

\begin{abstract}
The paper deals with the idea of the need for the dictionaries of stable units in each of the Slavic language. The register of the lexicographical works must include the word equivalents, phraseological units terminological units. For a new type of the dictionary the principles its arrangement are established. It is proved that such work will open new horizons for the further theoretical observations on the properties of the language system as well as its practical mastering. The dictionaries of the stable units will be of particular importance to the field of Slavic translation. Keywords: the dictionary of the stable units; stable unit; lexicography; translation lexicography; dictionary entry; the word equivalent terminological unit; phraseological unit
\end{abstract}

The program "Ukrainian lexicographical systems" which is a complex scientific theme of the Ukrainian language and Information Fund, NAS of Ukraine, where the algorithmic processing of lexicographical heritage is performed, largely contributed to the lexicographical researches of the Ukrainian linguists during the past two decades. It is worth recalling that the idea of automated dictionaries compiling was expressed by M. M. Peschak (See Peshchak, 1967) in the early 90's, one of the founders of the series "Dictionaries of Ukraine" was the director of the Ukrainian language and Information Fund, a member of the NAS of Ukraine, V. A. Shyrokov. Today, by the M. M. Peschak initiative, such important works as the two-volume "Pronouncing dictionary of the Ukrainian language" (2001, 2003), "Spelling dictionary of the Ukrainian language" (1994, 1999, 2002 ... 2010), the electronic publication "Dictionaries of Ukraine: an integrated lexicographical system. The paradigm. The transcription. The phraseology. The synonymy. The antonymy" (2001-2010), "Dictionary of Synonyms of the Ukrainian Language"(2001) and many other works were published, among which, obviously, the most important is edited in 2010: the 
first volume of the planned 20 of the "Dictionary of the Ukrainian language", this year already the 4 th volume of the lexicographical work saw the world.

Observing the rapid development of the Ukrainian lexicography, we may note that the translational aspect of the sphere is still on the scientific activity field periphery, and is mostly limited to the conclusion of the Ukrainian-Russian or Russian-Ukrainian dictionaries, through which we quite often get to know certain properties of different languages. The author of this article had published the "Russian-Ukrainian and Ukrainian-Russian dictionary of the word equivalents" (2003, 2004) in the series "Dictionaries of Ukraine" under the edition of M. Peschak. Our author team, which consisted of A. Luchyk, O. Antonova. and J. Dubrovsky, with the Department of the Slavic Studies of the Polish Academy of Sciences support, including V. Koseska-Tosheva and A. Kisel scientific editing has compiled and published the "Ukrainian-Polish dictionary of the word equivalents" (2011) and the "Polish-Ukrainian dictionary of the word equivalents" (2013). However, we consider, there is the need in compiling, among other types, the translation dictionaries of word equivalents of Slavonic character at least, for example the Ukrainian-Belarusian, Ukrainian-Czech dictionaries, etc.

Moreover, separately registered units, that due to their existence as well as their semantic content unity can be characterized as a word, in our terms word equivalents, are recorded in distantly related languages. In particular, the study carried out by O. Posobchuk on the prepositional equivalents example, states that these units are approximately equally common in Ukrainian, German and Spanish. The researcher ascertains: "The results of the study demonstrates that the prepositional word equivalents are not specific phenomenon characteristic to only one language or group of languages. These units are recorded in three languages belonging to different groups of Indo-European language family. In particular, in the Ukrainian language 152 prepositional WE are found, in German - 159 units, and in Spanish - 152" (Posobchuk, 2014).

The failure to determine in lexicographical practice the register words status to the separately registered structures that come into close paradigmatic-syntagmatic relations with other members of lexical and grammatical systems, and are their essential components, as we believe, is due to the lexicographic traditions as well as the scientific views state regarding the language system dynamic processes. Made by previous generations classification features element analysis, prompting most comprehensive studies the units' determination with full coverage of the classification criteria, presented modern language system statistics. We believe that the reflection of the language creative process is just a circle of those items that remain outside classification schemes, which are now defined as a linguistic system transient phenomenon; in particular, these are the words and equivalents. Detection of such structures, their parametrisation, formation determination, atypical features acquisition conditioning, ultimately, modeling their expression form and internal organization, on the one hand, will promote the knowledge of the language system development trends, and on the other - will make the necessary changes in the lexicographic practice.

A new way to the creative processes of knowledge in synchronous cut opens, after systemizing, including each of the Slavic languages, grammatical and lexi- 
cal material. Transitional linguistic phenomena, to name which scientists created special terminology - grammatical transformation, transposition, grammaticalization, desemantization, decategorization, conversion and so on, that are established and partially described by linguists can now be systematically and comprehensively presented in the form of the processes grammar, which should be created not contrary to the existing but as its logical extension. Thus, the paradigm of scientific research of the analysis of certain linguistic phenomena can be successfully transformed into their synthesis in particular refers to the phenomenon of transition in the language system, which undoubtedly will lead to the lexicographical works structural organization changes.

Of course, above all, the society has the needs in the basic lexicographical works translation, such as a idiomatic dictionary translated version into other Slavic languages and, conversely, reverse versions of such works' type, not to mention the translation into other world languages, including father related languages or unrelated languages. Almost all the Slavic languages have monolingual phraseological dictionaries. Today we have the historical and etymological dictionaries, including Russian phraseology, edited by V. M. Mokienko (Birikh, Mokienko, \& Stepanova, 2007). Although in each of the Slavic languages phraseological dictionaries are compiled according to their own principles, significant differences are observed even in the definition of the term phraseological unit, thus we can say that there is a clear base for the translation lexicography existence. If to consider the submission of the stable units in a particular language, they are fully represented in the basic explanatory dictionaries of a certain language.

In the Slavic lexicography all stable combinations in the dictionary are traditionally introduced by the $\diamond$ sign in the dictionary entry with a register word which is a part of a phraseologized unit as its main semantic center. In the linguistic perspective such an approach is justified. However, based on user needs, such dictionary organization of the material is quite inconvenient. This is due to several reasons. Firstly, the dictionary entry in this case can be quite voluminous, and in order to find a particular fixed combination, a lot of time is required. An example of this can be dictionary entries with register somatic units that since the Indo-European unity preserved lexical correspondents in the maximum number of languages, dialects and variants, among which the most genetic relationships reveal somatic units a foot, a hand as well as the others (See Luchyk, 2012a-b).

Thus, the register unit нога under the symbol $\diamond$ in «Словнику української мови» (further - СУМ) comprises more than 100 stable word-combinations (СУM, 1974, pp. 437-439), dictionary entry with the register unit рука - more than 250 (CУM, 1977, pp. 899-905); «Uniwersalny słownik języka polskiego PWN» (further - USJP) also includes more than 200 phraseological units after the word ręka (USJP, 2008b, pp. 948-951), 100 - after the word noga (USJP, 2008a, pp. 10111013.), and «Словарь русского языка» (further - СРЯ) with the register unit рука - 130 ( СРЯ, 1986, p. 506), нога - more than 60 stable word-combinations ( CPЯ, 1987, pp. 737-738). The positioning of the latest in these lexicographical sources, on the one hand, is done not in the alphabetical order, and the other the grate number of them is accompanied by links to other dictionary entries. For 


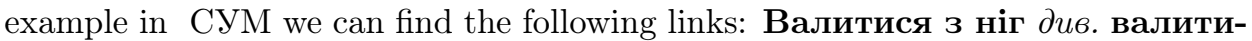
ся; Бути гирею на нозі див. гиря; in USPJ - Kula u nogi zob. Kula w zn. 2; Dać nogę zob. Dać w zn. 12b. The similar material arrangement is observed in СРЯ - В ногах правды нет $c$ м. правда; Земля горит под ногами $y$ кого см. гореть. It is obvious that under the necessity of the units properties clarifing such way of the material arrangement complicates the search to the user.

The compilers of the new "Dictionary of the Ukrainian language" (Словника української мови) in 20 volumes do it in the other way. In the preface to the dictionary concerning separately registered units, that are called phrases, is stated that in CYM-20 the stable phraseological units' zone that are following the word lexical meanings characteristics is allocated. The first group - stable phraseological units that are stable in its lexical combination, which consist mostly of words with their own meanings and are indivisible units in the communication process which may have a small desemantization of one component. The example of such phrases are considered to be груба їжа (word for word coarse food) - the simple, difficult for the digestion food; за алфавітом (word for word in alphabetical order) - in the alphabetical order of a certain language.

The second group consists of the word equivalents - a kind of periphrastic phrase units, equivalent to words that are integral stable reproduced units, which are equal to the lexical and grammatical classes of words (parts of speech) and with have the inherent lexical meaning without the components desemantization (завдяки тому, що; з того часу, як еtс.).

The third group is formed by the terminological phrase units related to different fields of knowledge and that are the relevant terminological systems part (анафілактичний шок, ератичні валуни еtс.).

A fourth group of phrases are the phraseological units - stable as to the composition and structure, indivisible lexical phraseological units that express specific integral phraseological meaning which is not its components meanings' sum, and occurs on the reinterpretation basis mainly due metaphorical and analogical processes (високо нестися, підводне каміння еtс.) (СУМ-20, 2010, pp. 24-25).

Such material arrangement, in our opinion, does not reduce the ways of finding a unit in the dictionary. Moreover, in this case, the requirements for the user's language grounding increase. In addition to the base knowledge of the arrangement of the main word in the phrase, the user must have an idea about the phrases' types: stable phraseological units, words' equivalents, terminological units or phraseological units themselves. Unfortunately, we can state that not even every linguist has this knowledge. Particular difficulties regarding separately registered units arise in translation, when there is the necessity, to translate a particular stable compound one has to consult the lexicographical work for several times, and it does not necessarily contribute to a positive outcome.

So, as we see it, there is an urgent need for the comprehensive lexicographical work of another type, the register of which would include separately registered units of all types, above all, this may be the ones that are distributed in CУM-20 among the four zones of stable units that is stable phraseological units, word equivalents, terminological units and phraseological units themselves. It is worth recalling that in the middle of the last century the famous Spanish linguist J. Casares had similar 
intentions. Having examined the stable expressions, properties, that are determined as sets of two or more words with constant component order and their semantic unity and that are characterized by uncertainty of association with a specific language levels, he emphasized: "In order to carry out a research, it is necessary to write a grammar of stable expressions" (Kasares, 1958). Although, unfortunately, today, this grammar is not created, but the lexicographical practice has all the prerequisites for the comprehensive dictionary of the stable phraseological units compiling, as the base of which will serve the interpretative, phraseological, terminological dictionaries of the word equivalents, and possibly in the future the dictionaries of sayings.

In the process of the Dictionary of the stable units of the Ukrainian language compiling it is necessary to take into account equally the inherent to all these structures peculiarities that is the separately registered units reproducibility and meaning stability, and those features that are mainly characteristic of one type of the stable expressions. Thus, only the word equivalents are characterized by belonging to the lexical and grammatical classes with the correspondent grammatical categories and syntactic relations. Their grammatical structure should be reflected in the left side of the dictionary, for example без кінця the adverb analog (аналог прислівника); з приводу того, що the conjunction (сполучник). Other principles of the Dictionary of stable phrases compiling are predetermined by on the one hand, the Slavic lexicographical tradition, on the other - the properties of the stable phrases that do not have a comprehensive systemic lexicographical description.

The lexical variation among all the stable units, is especially characteristic of phraseological units. According to the Ukrainian lexicographic tradition divergent elements of the register unit are situated in parentheses, that can be used in the dictionary: хоч вовків (собак, псів) гони (ганяй). Such material arrangement may be appropriate for the grammatical and phonetic fixing, that is related to the detailed pronunciation of a component or combination motivated by the desire to give the speech flow euphony, variants, that are mostly recorded in the word equivalents: інший раз (іншим разом), в (у) підсумку. Accent variants of a register part should be separated from each other by a semicolon: в (у) го́стях; в (у) гости́х. The phraseological units' variants that differ by the initial component may be situated in one dictionary entry if the component does not bring in significant semantic changes. These units are also separated from each other by a semicolon: горить (кипить) у руках (під руками); аж горить (кипить) у руках (під руками). As to the alphabetical order of the register units the variant is given with the reference to the source register unit: аж горить (кипить) у руках (під руками). див. горить (кипить) у руках (під руками); аж горить (кипить) у руках (під руками).

As a part of stable units optional structure components are fixed. They, are similarly to the punctuation variants submitted in broken brackets: $з$ (від) голови $<$ аж> до ніг (до п'ят); в (у) < тому $>$ разі $<,>$ якщо.

Being the register units all kinds of combinations as well as their orthoepic, morphological and punctuation variants should be located in the alphabetical order, which will certainly make it easier to find a particular unit as to the user who works 
with the material of one language system, and to those who are interested in the problem of translator referral.

Stylistic stratification, the scope of all stable expressions types' operation are quite different, so this property should be reflected in the dictionary. So, after the register unit at the left side, in addition to grammatical, if it exists, the remark, indicating stylistic, emotional, historical, branch feature of this phrase will be given: тим-то й ба; та тим-то й ба вигук, розм.; тепла компанія ірон.; тим $<,>$ що сполучник, застар.; абсолютний слух муз.

To each register unit the semantic characteristics in the form of interpretation is added. The interpretation of register units will initiate the right part of the dictionary entry, its place after the grammatical and stylistic marks, if they occur, as well as the the register unit: абсолютна істина фiлос. Об'єктивна реальність, що пізнається через ряд відносних істин.

As a significant part of stable expressions is not yet in its final status formation, the examples of the use of the register units in speech will contribute to their semantic properties disclosing. The illustrations based on journalistic texts and quotations from fiction works placed after the following dictionary explanatory entry will contribute to the knowledge of the register unit peculiarities, including its association with a particular lexico-grammatical word class:

на рівні ${ }^{1}$ аналог прийменника. Вказує на те, у повній відповідності до чого відбувається дія. Фермерсъкі господарства розвиваються на рівні вимог часу. на рівні ${ }^{2}$ у ролі присудка. Задовольняє найсуворіші вимоги. Його доповідъ була иілком на рівні.

If a register unit has two or more meanings, the phrases are given after each of them:

на днях прислівник 1. Незабаром. - Я прийду до тебе на днях; 2. У найближчий з минулих днів, декілька днів тому. На днях була громовии,я.

At the end of the dictionary entry the quotations from other fiction works and the XIX-XIX centuries authors works guided by their names or pen names will be given:

альма матер (рідше мати). Шаноблива назва навчального закладу (перев. університету) для випускників або тих, хто в ньому навчається. Сонце встає над школою - альма матер моїх друзів.

- Съогодні я торкнувся рукою моєї вірної «алъма матер». Вона надійна й несхитна, мудра і всезнаюча, як сама земля, як саме життл. - Це ти про кого? Про університет. Ю. Бедзик.

As an illustration of the stable phraseological units in the Dictionary of the Ukrainian language the following fragment is given:

БЕЗ Мі́РИ аналог прислівника. Дуже; у великій кількості; підкреслює велику кількість ознаки. - Я без міри щасливий.

I тільки що човни уздріли (арпадяни), То всі злякалися без міри, Один к трояни,ям підступив. І. Котляревський. 


\section{БЕЗНАДІ̆ЙНИЙ ДУРЕНЬ. Әив. НАБИТИЙ (БИТИЙ, НЕПОПРАВ- НИЙ, ЗАПЛІШЕНИЙ) ДУРЕНЬ}

БЕЗУМОВНИЙ РЕФЛЕКС фiзл. Вроджений рефлекс, на відміну від умовного, набутого. Безумовний рефлекс виникає переважно під впливом контактного подразнення.

Безумовний рефлекс - ие спадково закріплена форма реагування на біологічно значущі дї зовнішнъого світу. 3 наук. літ-ри. Безумовні рефлекси створювалися протягом тривалого періоду розвитку даного виду тварин. 3 наук. літ-ри.

БЕЗ УПЙНУ (ВПЙНУ, СПЙНУ) прислівник. Не зупиняючись, не стримуючи себе від будь-яких дій, безперервно; так, що не можна зупинити. Дощ, хлюпав без упину.

В далекому Сан-Ремо на березі Середземного моря спалахи хвиль у місячну ніч викликають у неї асоціацї̈ з озброеною народною силою, що без упину йде на приступ твердинъ тиранї. Л. Українка.

Comprehending that the Stable Units Dictionary compilation requires a lot of efforts from the experienced lexicographers team, we note that in the modern lexicography all necessary conditions for its existence are created. The publication of this important work will open the new horizons for the further theoretical observations on the language system properties as well as its practical mastering. The mentioned work is considered to be important in the field of translation, including Slavic, general and comparative linguistics.

\section{References}

Birikh, A. K., Mokienko, V. M., \& Stepanova, L. I. (2007). Russkaia frazeologiia: Istorikoetimologicheskiu slovar'. Moskva: Astrel'.

Evgen'eva, A. P. (Ed.). (1986). Slovar' russkogo iazyka: V 4-kh t. [CPЯ] (Vol. 2). Moskva.

Evgen'eva, A. P. (Ed.). (1987). Slovar' russkogo iazyka: V 4-kh t. [CPЯ] (Vol. 3). Moskva.

Kasares, K. (1958). Vvedenie v sovremennuiu leksikografiiu. Moskva: Izdatel'stvo inostrannoŭ literatury.

Luchyk, A. A. (2012a). Verbal'na model' zovnishn'oho portreta slov'ianyna (na materiali «Etymolohichnoho slovnyka ukraïns'koï movy»). In Aktsentolohiia. Etimolohiia. Semantyka: Do 75-richchia akademika NAN Ukraïny V. H. Skliarenka (pp. 407-417). Kyïv.

Luchyk, A. A. (2012b). Henetychni zv'iazky ukraïns'kykh somatyzmiv z ïkhnimy vidpovidnykamy u neslov'ians'kykh movakh (na materiali «Etymolohichnoho slovnyka ukraïns'koï movy»). In Suchasni doslidzhennia z inozemnoï filolohï: Zb. nauk. prats' (N. 10, pp. 202-207). Uzhhorod.

Peshchak, M. M. (1967). Elektronno-obchysliuval'ni mashyny i pidgotovka Hidronimichnoho atlasu Ukraïny. Povidomlennia Ukraïns'koï onomastychnoï komisï, (3), 50-55.

Peshchak, M. M. (1975). Opyt formalizovannogo analiza leksicheskogo znacheniia slova. In Sopostavitel'noe issledovanie russkogo i ukrainskogo iazykov (pp. 122-141). Kyïv: Naukova dumka. 
Peshchak, M. M. et al. (1986). Leksychna semantyka v systemi «liudyna-mashyna». Kyïv. Posobchuk, O. (2014). Dvokomponentni pryı̆mennykovi ekvivalenty slova v ukraïns'kiı̆, nimets'kiŭ ta ispans'kiŭ movakh. In Mova i sotsium: Etnokul'turnyı aspekt: Materialy IV Mizhnarodnoï naukovoï konferentsï molodykh uchenykh ( $m$. Berdians'k, 19-20 veresnia 2014 r.): (Zbirnyk tez). Berdians'k: BDPU.

Slovnyk ukraïns'koï movy: V 11-ty t. [CУM]. (1974). (Vol. 5). Kyïv.

Slovnyk ukraïns'koï movy: V 11-ty t. [CУM]. (1977). (Vol. 7). Kyïv.

Slovnyk ukraïns'koï movy: U 20-ty t. [CYM-20]. (2010). (Vol. 1). Kyïv.

Uniwersalny stownik języka polskiego PWN [USJP]. (2008a). (Vol. 2). Warszawa: PWN.

Uniwersalny słownik języka polskiego PWN [USJP]. (2008b). (Vol. 3). Warszawa: PWN.

\section{Acknowledgment}

This work was supported by a core funding for statutory activities from the National University of "Kyiv-Mohyla Academy", Kyiv, Ukraine.

The author declares that she has no competing interests.

This is an Open Access article distributed under the terms of the Creative Commons Attribution 3.0 PL License (http://creativecommons.org/licenses/by/3.0/pl/), which permits redistribution, commercial and non-commercial, provided that the article is properly cited.

(C) The Author 2015

Publisher:

Institute of Slavic Studies, PAS, University of Silesia \& The Slavic Foundation 